\title{
Matrix Hard - The Impact of Technological, Economic and Social Indicators on Productivity and Competitiveness
}

\author{
Marina Popa* and Maia Pisaniuc
}

Academy of Economic Studies of Moldova, Moldova

$\begin{array}{ll}\text { ARTICLE INFO } & \text { ABSTRACT } \\ \text { Keywords: } & \text { The objective of this research is to demonstrate the impact of } \\ \text { Productivity } & \text { technological, economic and social indicators on productivity and } \\ \text { Economic Indicator } & \text { competitiveness through the HARD Matrix method, proposed by the } \\ \text { Social Indicator } & \text { European Commission. The level of economic development of } \\ \text { Innovation } & \text { different countries, as well as the degree of diversification and } \\ & \text { specialization of their world production, determines the degree of } \\ \text { integration of national economies in the world economy that differs } \\ \text { considerably by country and group of countries. The expansion and } \\ \text { amplification of the internationalization process have substantially } \\ \text { changed the place and role of each state in the world economy. Due to } \\ \text { this process, today's world economy is no longer a simple sum of } \\ \text { economies put in contact, but a global-universal system, unitary } \\ \text { through the interrelationships between the component subsystems and } \\ \text { its extremely heterogeneous structure. In the twenty first-century, the } \\ \text { process of amplifying innovation, the net economy, and the Covid 19 } \\ \text { pandemic have shaped new trends in the world countries and } \\ \text { determined the balance of power between the three great empires of } \\ \text { the world - the United States, the European Union, and China. At the } \\ \text { same time, there are no similar links between the United States, the } \\ \text { European Union and China, they do not share the same culture, do not } \\ \text { share the same geographic space, and do not use the same models of } \\ \text { economic development, but all of them consider innovation, } \\ \text { sophisticated business, technology, safe tools in promoting economic } \\ \text { growthand competitiveness. }\end{array}$

\section{Introduction}

The end of the twentieth century and the beginning of the twenty-first century were marked by a series of events that led to the creation of a new type of socioeconomic society, which the New Cambridge School calls the new economy, the informational society, the knowledge society, being influenced by major vectors such as innovational business, internationalization, transnationalization, and globalization. In this context, the world economy was influenced by a set of changes that have contributed to the design of new trends and features, resulting from the evolution of pre-industrial to postindustrial stages of economic development. According to which world economies have moved toward an innovation-based society, communication, information, and creativity. (Porter, 2008) In the current conditions, terms such as innovative economy, globalization, sophisticated business are not a novelty for the contemporary economy, but they are vital phenomena for the global economic process. The wave of globalization from nowadays and implicitly that of internationalization, characterized by net reductions in commercial barriers and the costs of transport, communication, and information, offers various opportunities to national economies. The participation of the states of the world in the world economic system represents the intrinsic condition of the progress and evolution of

\footnotetext{
* Corresponding author E-mail address: popa.marina.vasile@ ase.md 
the civilization of the twenty - first century, thus becoming an integral part of an increasingly unitary global economy.

The analysis of the theoretical and methodological scientific approaches regarding the increase of labour productivity in the conditions of internationalization of national economies allows us to formulate the significant scientific problem that was solved. It consists of identifying the factors that contribute to the increase of labor productivity in the national economy, using the HARD Matrix methodology.

In this context, the author aims to make a comparative analysis between three types of indicators: economic, innovative, and social, to determine which has a more precise influence on increasing the productivity and competitiveness of states, which is also the main objective of the research.

The research comprises an introduction, the research methodology, results, conclusions, and bibliography.

\section{Literature Review for This Study}

In the elaboration of the article, the author researched the specialty literature and the hypotheses of several national authors and international economists such as K. Schwab (2017), L. Voinea (2007) (2010), M. Porter (2008). Significant importance in supporting the demonstrated theories had the economic reports of the European Commission, the statistical data provided by EUROSTAT, the World Bank, UNCTAD, and the National Bureau of Statistics.

\section{Methods}

Following the conducted research on identifying the factors of increasing labor productivity, we developed a model for determining the principal indicators for its increase. Based on this model, we will analyse the level of the Labour Productivity Index both in the Republic of Moldova and in other states. The central objective of the calculation of the Labor Productivity Index is to establish the factors that influence and have a direct impact on it. To carry out this analysis, we used as a benchmark the 'Hard' Matrix, developed within the GOF Project 'Romania- Building Regional Assessment Capacity in Line with the Lisbon Agenda' under the leadership of the Romanian economist Liviu Voinea. (Voinea, 2007)

Our model starts from the structural indicators found in international statistics, in particular, we used the categories of indicators proposed by the World Bank, grouped into the following categories: general economic environment, employment, innovation, and research.

Considering these elements and the factors that influence labour productivity, we obtain three types of categories, as follows: (Voinea, 2010)

- Economic indicators (general economic environment);

- Social indicators (employment);

- Technological indicators (innovation and research).

Table 1.

Calculation of the Labor Productivity Index, according to the "Hard" Matrix Method

\begin{tabular}{|c|c|c|c|c|c|}
\hline \multicolumn{2}{|c|}{ Economic Indicator (IE) } & \multicolumn{2}{|c|}{ Social Indicator (IS) } & \multicolumn{2}{|c|}{ Technological Indicator (IT) } \\
\hline Category & Weight & Category & Weight & Category & Weight \\
\hline E1 - GDP/per capita & 30 & S1 - Degree of literacy & 30 & $\begin{array}{l}\text { T1- Expenses on research } \\
\text { and development as in GDP }\end{array}$ & 20 \\
\hline E2 - GDP growth rate & 10 & S2 - Total labor force & 40 & $\begin{array}{l}\text { T2- Employed population } \\
\text { with higher education }\end{array}$ & 30 \\
\hline E3 - Net exports & 30 & $\begin{array}{l}\text { S3 - Employment - } \\
\text { women }\end{array}$ & 10 & T3-Number of scientists & 20 \\
\hline E4 - FDI inputs & 30 & $\begin{array}{l}\text { S4-Average life } \\
\text { expectancy index }\end{array}$ & 20 & $\begin{array}{l}\text { T4- Patent applications } \\
\text { (inhabitants) }\end{array}$ & 30 \\
\hline
\end{tabular}

Source: Developed by the author based on Voinea L. (2007) 
Following the weighting of these three indicators, is established the calculation formula of the Labor Productivity Index (LPI) (the sum of the used weights has a value of 100). Each of these indicators is calculated as a weighted average of the variables selected from each group.

This leads to the following calculation model for the three indicators:

$I_{E}=\frac{30 E 1+10 E 2+30 E 3+30 E 4}{100}$

$I_{S}=\frac{30 S 1+40 S 2+10 S 3+20 S 4}{100}$

$I_{T}=\frac{20 T 1+30 T 2+20 T 3+30 T 4}{100}$

In the end, the value of the Labor Productivity Index, ILP, is given by the weighted average of the three indicators, economic, social, and technological:

$I_{L P}=\frac{40 E I+30 S I+30 T I}{100}$

The calculations reflect the contribution of each of the three sub-indicators to the labor productivity indicator. In general, countries with high economic growth, a high degree of innovation, and a high employment rate also tend to have higher labor productivity.

At the same time, in the author's conception, this calculation method makes a much more objective assessment of the level of labor productivity than the relation of GDP does to the labor force.

\section{Data Analysis and Results of Research}

\section{The Results of the Research in Some Chosen Countries}

This analysis was made in several countries for 2018. The high level of productivity present in the American economy attracts enormous capital flows but also allows the export of commercial and financial resources all over the world. Economic growth, supported by highperformance technology, intensively promotes the economic concept related to the global productivity of production factors, a phenomenon that emphasizes the effectiveness with which the American economy combines employee work with investment in research and innovation. In the United States, increasing labor productivity is experiencing large but shortterm fluctuations and some changes marked by economic cycles. Since the post-war period, there was a tendency to increase labor productivity until the recession of 1967 and slower until the early 1980s, with very uneven and very fluctuating recovery delays. From 1995 until now, the "new economy" has generated a dramatic increase in labor productivity.

Using the HARD Matrix method, we can easily identify which are the factors with a considerable impact on United States economic development. Following the calculations made by the author, it was established that the LPI is 92.32 , which explains that the United States is a country with increased labor productivity. 
Table 2.

Calculation of indicators that influence labor productivity in the United States according to the Hard Matrix method (2018)

\begin{tabular}{|c|c|c|c|c|c|}
\hline \multicolumn{2}{|c|}{ Economic Indicator $(E I)$} & \multicolumn{2}{|c|}{ Social Indicator $(S I)$} & \multicolumn{2}{|c|}{ Technological Indicator (TI) } \\
\hline Category & Weight & Category & Weight & Category & Weight \\
\hline $\begin{array}{l}\text { E1 - } \\
\text { GDP/per capita }\end{array}$ & $55836 * 30 \%$ & $\begin{array}{l}\text { S1 - } \\
\text { Degree of literacy }\end{array}$ & $97 * 30 \%$ & $\begin{array}{l}\text { T1- Expenses on research } \\
\text { and development as \% of } \\
\text { GDP }\end{array}$ & $2,8 * 20 \%$ \\
\hline $\begin{array}{l}\text { E2 - } \\
\text { GDP growth rate }\end{array}$ & $2,9 * 10 \%$ & $\begin{array}{l}\text { S2 }- \\
\text { Total labor force }\end{array}$ & $165348 * 40 \%$ & $\begin{array}{l}\text { T2- Employed population } \\
\text { with higher education }\end{array}$ & $62832 * 30 \%$ \\
\hline $\begin{array}{l}\text { E3- } \\
\text { Net exports }\end{array}$ & $2223624 * 30 \%$ & $\begin{array}{l}\text { S3 - } \\
\text { Employment - women }\end{array}$ & $77166 * 10 \%$ & T3-Number of scientists & $14567 * 20 \%$ \\
\hline $\begin{array}{l}\text { E4 - } \\
\text { FDI inputs }\end{array}$ & $378894 * 30 \%$ & $\begin{array}{l}\text { S4- } \\
\text { Average life expectancy } \\
\text { index }\end{array}$ & $79 * 20 \%$ & $\begin{array}{l}\text { T4- Triadic patent families } \\
\text { (inhabitants) }\end{array}$ & $15346 * 30 \%$ \\
\hline Calculated EI & $7978(86 \%)$ & Calculated SI & $729(8 \%)$ & Calculated TI & $525(6 \%)$ \\
\hline \multicolumn{6}{|c|}{ Labor Productivity Index, US $=92,32$} \\
\hline
\end{tabular}

Source: Author's calculations based on the HARD Matrix model and World Bank (2020) and United Nations Conference of Trade and Development (2020)

The economic indicator is the factor with the greatest impact on labor productivity, which means that the added value obtained from exports, FDI inputs are the main determinants in its increase. At the same time, the considerable differences between the technological and the economic indicator are reflected by the high weight of the American GDP however, it does not mean that the impact of the social and technological index is lower on the increase of productivity and competitiveness. (Popa, 2015)

Therefore, the high degree of competitiveness and development of the American economy is determined by several aspects: sophisticated business models, the American human potential is among the best in the world, it is the origin country of the most giant, creative and innovative transnational companies in the world; the US dollar is the main international instrument of payment and reserve; English language, which is a vehicle of culture, facilitating the expansion of the American lifestyle to countries with old traditions, endowment with factors and intensive specialization, highly developed domestic competitive environment. (Schwab, K., 2017)

Another country analyzed in our research is Japan. Japan is an important mega-center in the Asian economic space. It is the most advanced country in the world in terms of technological development, and the third country in the world in terms of GDP. Japan is also a major trading force, ranking 4th in world exports. (UNCTAD 2020) It is also a solid financial center, the Tokyo Stock Exchange being one of the most important global financial centers for capitalization and financial transactions.

Calculating the Labor Productivity Index (LPI) in Japan, with the Hard Matrix method, it was established that the LPI is 16.40 , which explains that Japan is a country with a lower level of labor productivity compared to the United States.

Table 3.

Calculation of indicators that influence labor productivity in Japan according to the Hard Matrix method (2018)

\begin{tabular}{|c|c|c|c|c|c|}
\hline \multicolumn{2}{|c|}{ Economic Indicator $(E I)$} & \multicolumn{2}{|c|}{ Social Indicator $(S I)$} & \multicolumn{2}{|c|}{ TechnologicalIndicator (TI) } \\
\hline Category & Weight & Category & Weight & Category & Weight \\
\hline $\begin{array}{l}\text { E1 - } \\
\text { PIB/per capita }\end{array}$ & $32227 * 30 \%$ & $\mathrm{~S} 1$ - Degree of literacy & $99 * 30 \%$ & $\begin{array}{l}\text { T1- Expenses on research and } \\
\text { development as \% of GDP }\end{array}$ & $3,4 * 20 \%$ \\
\hline $\begin{array}{l}\text { E2 - } \\
\text { GDP growth rate }\end{array}$ & $0,47 * 10 \%$ & $\begin{array}{l}\mathrm{S} 2- \\
\text { Total labor force }\end{array}$ & $65348 * 40 \%$ & $\begin{array}{l}\text { T2- Employed population with } \\
\text { higher education }\end{array}$ & $32832 * 30 \%$ \\
\hline $\begin{array}{l}\text { E3 - } \\
\text { Net exports }\end{array}$ & $732146 * 30 \%$ & $\begin{array}{l}\text { S3- } \\
\text { Employment - women }\end{array}$ & $27166^{*} 10 \%$ & T3-Number of scientists & $926671 * 20 \%$ \\
\hline $\begin{array}{l}\text { E4 - } \\
\text { FDI inputs }\end{array}$ & $-2250 * 30 \%$ & $\begin{array}{l}\text { S4 - } \\
\text { Average life expectancy } \\
\text { index }\end{array}$ & $89 * 20 \%$ & $\begin{array}{l}\text { T4- Triadic patent families } \\
\text { (inhabitants) }\end{array}$ & $16946 * 30 \%$ \\
\hline Calculated EI & $2299(50 \%)$ & Calculated SI & $289(6 \%)$ & Calculated TI & $2002(44 \%)$ \\
\hline
\end{tabular}




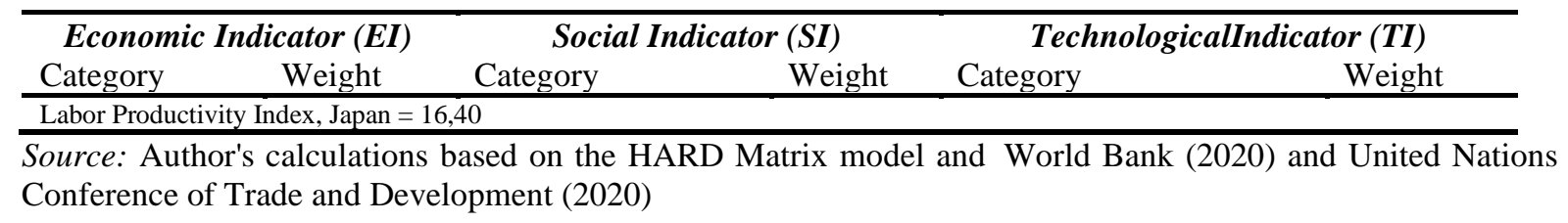

The economic indicator is practically equal to the technological one as a weight, but as an impact, innovation determines the increase of labor productivity the most. The extremely low weight of the social index demonstrates the severe demographic problems and the lack of labor force that Japan faces today.

To increase the level of labor productivity and reset the entire economy, Japan must quickly take several measures:

- Slowing the tendency of decrease in the labor force by increasing the employment rate of women, thus reducing inequalities between the active female and male labor force. Another measure would be to increase the employment of foreign workers;

- Improving the business environment by successfully using advanced innovative business models to stimulate increased labor productivity by promoting flexibility and mobility in the labor market, establishing a more favorable climate for foreign entrepreneurs, boosting capital inflows to facilitate entrepreneurship and innovation;

- Reduction of public debt (OCDE, 2015).

The Labor Productivity Index of the European Union, calculated with the Hard Matrix method, is 59.1, which is the European average. The author calculated the LPI for the European Union as a whole of 27 states. It is worth mentioning that the indicator may be different if we calculate each EU country separately. Table 1.3 describes the analyses and calculations of the European average index.

Table 4.

Calculation of indicators that influence labor productivity in the European Union according to the Hard Matrix method (2018)

\begin{tabular}{|c|c|c|c|c|c|}
\hline \multicolumn{2}{|c|}{ Economic Indicator $(E I)$} & \multicolumn{2}{|c|}{ Social Indicator $(S I)$} & \multicolumn{2}{|c|}{ Technological Indicator (TI) } \\
\hline Category & Weight & Category & Weight & Category & Weight \\
\hline $\begin{array}{l}\text { E1 - } \\
\text { PIB/per capita }\end{array}$ & $31668 * 30 \%$ & $\begin{array}{l}\mathrm{S} 1- \\
\text { Degree of literacy }\end{array}$ & $95 * 30 \%$ & $\begin{array}{l}\text { T1- Expenses on research and } \\
\text { development as \% of GDP }\end{array}$ & $2,03 * 20 \%$ \\
\hline $\begin{array}{l}\text { E2 - } \\
\text { GDP growth rate }\end{array}$ & $1,96 * 10 \%$ & $\begin{array}{l}\mathrm{S} 2- \\
\text { Total labor force }\end{array}$ & $248347 * 40 \%$ & $\begin{array}{l}\text { T2- Employed population with } \\
\text { higher education }\end{array}$ & $149008 * 30 \%$ \\
\hline $\begin{array}{l}\text { E3- } \\
\text { Net exports }\end{array}$ & $7115901 * 30 \%$ & $\begin{array}{l}\text { S3 - } \\
\text { Employment - women }\end{array}$ & $112259 * 10 \%$ & T3-Number of scientists & $2801321 * 20 \%$ \\
\hline $\begin{array}{l}\text { E4- } \\
\text { FDI inputs }\end{array}$ & $439458 * 30 \%$ & $\begin{array}{l}\mathrm{S} 4- \\
\text { Average life expectancy } \\
\text { index }\end{array}$ & $81 * 20 \%$ & $\begin{array}{l}\text { T4- Triadic patent families } \\
\text { (inhabitants) }\end{array}$ & $14568 * 30 \%$ \\
\hline Calculated EI & $9104(55,84)$ & Calculated SI & $\begin{array}{l}1105 \\
(6,78 \%)\end{array}$ & Calculated TI & $6093(37,37 \%)$ \\
\hline \multicolumn{6}{|c|}{ Labor Productivity Index, European Union $=59,1$} \\
\hline
\end{tabular}

The economic indicator and the technological indicator are the main determinants of labor productivity, which means that the benefit obtained from exports, FDI inputs are the main factors in its increase. As in the case of the correlation method, it is observed that investments in research, development, intelligent human factor, education, patents are factors that directly influence the increase of labor productivity in the European Union. On the other hand, the social index has a very low weight, which confirms serious unemployment problems, the refugee crisis, and the lack of jobs. (European Commission, 2015). 
Using the Hard Matrix method in the case of the Republic of Moldova, it proved that the Economic Indicator is the one that has a more powerful impact than the social and technological indicator. Such a considerable gap between indicators (Economic Indicator $57 \%$, Social Indicator 27\%, Technological Indicator 15\%) confirms the results obtained previously regarding the importance of specific factors in increasing labor productivity in the national economy. The Republic of Moldova is a country at the stage of development based on primary factors, and the technological and innovative concept is just at the beginning moreover, their influence on increasing labor productivity is determined by only $15 \%$.

Table 5.

Calculation of indicators that influence labor productivity in the Republic of Moldova according to the Hard Matrix method (2018)

\begin{tabular}{|c|c|c|c|c|c|}
\hline \multicolumn{2}{|c|}{ Economic Indicator $(E I)$} & \multicolumn{2}{|c|}{ Social Indicator $($ SI) } & \multicolumn{2}{|c|}{ Technological Indicator (TI) } \\
\hline Category & Weight & Category & Weight & Category & Weight \\
\hline $\begin{array}{l}\text { E1 - } \\
\text { PIB/per capita }\end{array}$ & $1589 * 30 \%$ & $\begin{array}{l}\text { S1 - } \\
\text { Degree of literacy }\end{array}$ & $98 * 30 \%$ & $\begin{array}{l}\text { T1-Expenses on research and } \\
\text { development as \% of GDP }\end{array}$ & $2,5 * 20 \%$ \\
\hline $\begin{array}{l}\text { E2 - } \\
\text { GDP growth } \\
\text { rate }\end{array}$ & $-0,5 * 10 \%$ & $\begin{array}{l}\mathrm{S} 2- \\
\text { Total labor force }\end{array}$ & $1255 * 40 \%$ & $\begin{array}{l}\text { T2- Employed population } \\
\text { with higher education }\end{array}$ & $485 * 30 \%$ \\
\hline $\begin{array}{l}\text { E3 - } \\
\text { Net Exports }\end{array}$ & $2482 * 30 \%$ & $\begin{array}{l}\mathrm{S} 3- \\
\text { Employment - } \\
\text { women }\end{array}$ & $620 * 10 \%$ & T3-Number of scientists & $1750 * 20 \%$ \\
\hline $\begin{array}{l}\text { E4 - } \\
\text { FDI inputs }\end{array}$ & $228 * 30 \%$ & $\begin{array}{l}\text { S4 - } \\
\text { Average life } \\
\text { expectancy index }\end{array}$ & $71 * 20 \%$ & $\begin{array}{l}\text { T4- Triadic patent } \\
\text { families (inhabitants) }\end{array}$ & $64 * 30 \%$ \\
\hline Calculated EI & $12.83(57,12 \%)$ & Calculated SI & $\begin{array}{c}6.14 \\
(27,33 \%)\end{array}$ & Calculated TI & $3.49(15,55 \%)$ \\
\hline
\end{tabular}

Source: author's calculations based on the HARD Matrix model and World Bank (2020), United Nations Conference of Trade and Development (2020), National Bureau of Statistics (2020)

Making a comparative analysis between the Republic of Moldova and the states analyzed above, we perceive that the gaps are tremendous.

At the same time, we see gaps in indicators at the national level. The Republic of Moldova is divided into three principal regions: The Northern Development Region (NDR), the Southern Development Region (SDR), and the Central Development Region (CDR). By calculating the Productivity Index for each region individually, we can determine which of them is more attractive for investment and promotion of innovational business. (Popa, 2011)

That is a new approach for the Republic of Moldova about identifying the factors of increasing labor productivity by calculating the Labor Productivity Index (LPI) with the Hard Matrix method for each region of economic development in the country. Following the calculations of LPI, a curious aspect emerges. The LPI in Chisinau is 0.101, which is a higher indicator than the national one. That result confirms the idea stated above regarding the major discrepancies between the level of development registered in Chisinau in contrast to the rest regions of the country.

Table 6.

Calculation of indicators that influence labor productivity in the developing regions of the Republic of Moldova according to the Hard Matrix method

\begin{tabular}{ccccccc}
\hline \multicolumn{2}{c}{$\boldsymbol{E} \boldsymbol{c}$ Sonomic Indicator $(\boldsymbol{E I})$} & \multicolumn{2}{c}{ Social Indicator $($ SI) } & \multicolumn{2}{c}{ Technological Indicator (TI) } & LPI \\
Region & Weight & Region & Weight & Region & Weight & \\
\hline NDR & 9,53 & NDR & 2,21 & NDR & 1,52 & \multirow{2}{*}{, 063 } \\
& $(72 \%)$ & & $(16,70 \%)$ & & $(11,29 \%)$ & \\
CDR & 3,95 & CDR & 1,80 & CDR & 0,90 & $\mathbf{0 , 0 5 1}$ \\
& $(59,39 \%)$ & & $(27,06 \%)$ & & $(13,55 \%)$ & \\
\hline
\end{tabular}




\begin{tabular}{|c|c|c|c|c|c|c|}
\hline \multicolumn{2}{|c|}{ Economic Indicator $(E I)$} & \multicolumn{2}{|c|}{ Social Indicator $($ SI) } & \multicolumn{2}{|c|}{ Technological Indicator (TI) } & \multirow[t]{2}{*}{$L P I$} \\
\hline Region & Weight & Region & Weight & Region & Weight & \\
\hline$\overline{\text { SDR }}$ & $\begin{array}{c}5,01 \\
(75,67 \%)\end{array}$ & SDR & $\begin{array}{c}1,11 \\
(16,76 \%)\end{array}$ & SDR & $\begin{array}{c}0,50 \\
(7,57 \%)\end{array}$ & 0,045 \\
\hline Chișinău & $\begin{array}{c}24.83 \\
(80,20 \%)\end{array}$ & Chișinău & $\begin{array}{c}3,12 \\
(10,07 \%)\end{array}$ & Chișinău & $\begin{array}{c}3,01 \\
(9,72 \%)\end{array}$ & 0,151 \\
\hline
\end{tabular}

Source: Author's calculations based on the HARD Matrix model and National Bureau of Statistics (2020)

Using this method for developing regions in the Republic of Moldova, it was established that the Economic Indicator is the one that has a much higher net impact than the social and technological indicator. Such a large gap between indicators demonstrates the same characteristic hypothesis for the entire economy, namely, the fact that regions are poorly developed economically, based on primary factors, and the technological and innovation concept is underdeveloped, thus the transition from Factor Driven to Efficiency Driven is about the future. (Popa, 2017)

\section{Conclusions}

Following the calculations made by the author, based on the Hard Matrix Method, it was established that the LPI in the USA is 92.32, in Japan is 16.40, and in the European Union 27, it is 59.1, which explains that there are countries with increased labor productivity. In the United States, the economic indicator is the factor with the greatest impact on labour productivity. In Japan, the economic indicator is practically equal to the technological one regarding weight, but as an impact, innovation determines the increase of labor productivity the most. In European Union countries, the economic indicator and the technological indicator are the main determinants of labor productivity.

Using the method Hard Matrix to determine the factors of increasing labor productivity in the Republic of Moldova, including in its developing regions, it was established that the Economic Indicator is the one that has a net impact higher than the social and technological indicator. Such a large gap between them demonstrates the same characteristic hypothesis for the entire economy, specifically, the fact that regions are poorly developed economically, based on primary factors, and the technological and innovation concept is underdeveloped, moreover the transition from Factor Driven to Efficiency Driven is about the future. There is a substantial difference between Productivity Indexes calculated between regions and Chisinau.

For the Republic of Moldova, the author identifies the factors for increasing labor productivity by calculating the Labor Productivity Index (LPI) by the Hard Matrix method and for each region of economic development in the country. Following the calculations of the LPI, an interesting aspect is outlined. The LPI in Chisinau is 0.101 , which is a higher indicator than the national one. This result confirms the major discrepancies between the level of development registered in Chisinau compared to the rest of the regions in the country.

\section{Acknowledgment}

This article is the result of studies conducted in the National Research Project No. 20.80009.1606.42: Configurarea businessului inovațional în contextul concurenței regionale.

\section{References}

European Commission (2015). State of the innovation union, 2015. [online]. Available at: $<$ https://op.europa.eu/en/publication-detail/-/publication/0487b7b9-b5d6-11e5-8d3c01aa75ed71a1/language-en/format-PDF/source-71238593> [Accessed on 9 april 2020].

National Bureau of Statistics (2020). Public database. [online] Available at: https:// statistica.gov.md / [Accessed on 17 october 2020]. 
Organization for Economic Co-operation and Development, (2015). The future of productivity. OCDE, $2015 . \quad$ [online]. Available at:http://www.oecd.org/economy/growth/OECD2015-The-future-of-productivity-book.pdf (Accessed: 25 january 2020)

Popa, M., (2015). The innovation of the United States and the European Union in the conditions of global competition. In: European Studies. Chisinau, 2015, nr. 6, p. 148-165. ISSN 2345-1041. Index Gesis-SSOAR [online]. Available at: http://studiieu.org/files/publications /SE\%20N6.pdf (Accessed: 21 december 2019)

Popa M., (2011). The need to develop a smart industrial policy in the Republic of Moldava. In: International Scientific Conference "Republic of Moldova: 20 years of economic reforms ", (23-24 sept. 2011). Chişinău: 2011, vol. 1, p. 403-407.

Popa, M., (2017). The economy of the Republic of Moldova at 25 years of independence. Its perpetuation in the stage of economic development Factor Driven. In: European Studies. Chişinău, 2017, Nr.9., p.75-99. 0,87 c.a, ISSN 2345-1041 ISSN-L 2345-1041, Index Gesis-SSOAR [online]. Available at: http://studiieu.org/files/publications/SE-9-201747758.pdf (Accessed: 14 september 2020)

Porter, M., (2008). On Competition, Updated and Expanded Edition. The Harvard Business Review book series, ISBN 142212696X, 9781422126967. 576 p.

Schwab, K., (2017). The Global Competitiveness Report 2017-2018. World Economic

Forum. Geneva, Switzerland (2017). 393 p. ISBN ISBN-13: 978-1-944835-11-8 [online]. Available at: http://www3.weforum.org/docs/GCR20172018/05FullReport/ TheGlobalCompetitivenessReport2017\%E2\%80\%932018.pdf (Accessed: 03 September 2020)

The World Bank (2020). Open database/Economy and Growth. [online] Available at: https://data.worldbank.org [Accessed on 25 September 2020]

United Nations Conference on Trade and Development (UNCTAD) (2020). Data Center/ Economic Trends. [online] Available at: https://unctadstat.unctad.org/EN/ [Accessed on 25 September 2020]

Voinea, L., (2007). Regional competitiveness assessment matrix: who is it used for and how is it done? Regional Competitiveness Assessment Book. Bucharest: AEG, 2007. 22-26, p.

Voinea, L., (2010). Romania's reindustrialization: Policies and strategies. Study conducted by the Applied Economics Group - AEG. Bucharest: AEG, 2010. 172 p. 